\title{
INTERSTATE TRADE BARRIERS IN THE UNITED STATES
}

\author{
Paul T. Truitr*
}

An interstate trade barrier has been defined as "a statute, regulation or practice which operates or tends to operate to the disadvantage of persons, products, or services coming from sister states to the advantage of local residents, products or enterprises." Examples of trade barriers are found widely distributed in substantial numbers among laws, ordinances, rules, regulations and administrative orders regulating production, distribution, and general commercial practice. These restrictive influences affect adversely the economical and practical operation of the marketing system. At present there is a lack of economic understanding of these laws; also, their broad vital implications are not sufficiently realized. This is doubtless due to the fact that the phenomenal growth of trade barriers is of comparatively recent origin.

Trade barriers have been divided into four types or classes. ${ }^{2}$ These are (I) laws which on their face manifest a discriminatory purpose directed at out-of-state competition; $;^{3}$ (2) laws which on their face are non-discriminatory, but which are discriminatory in practice; ${ }^{4}$ (3) laws which on their face apply to residents and nonresidents alike, but which in operation burden out-of-state enterprise. The cumulative effect of such laws constitutes a trade barrier; ${ }^{5}$ (4) laws which in effect

- B.S. in Business and Public Administration, x924, University of Missouri. Since Nov. 1939, Chairman of the Interdepartmental Committee on Interstate Trade Barriers. Staff member, Division of Regional Economy, Bureau of Foreign and Domestic Commerce. Formerly economic analyst in the Procurement Division, U. S. Treasury. Extensive previous experience in private industry as operating executive, analyst, and buyer.

${ }^{2}$ Definition used for the trade barrier in 12 Hearings before the Temporary National Economic Committee, 76th Cong., 2d Sess. (1940) No. 10, at 265, hereinafter cited as T. N. E. C. Hearings.

2 Testimony, A. H. Martin, Jr., Director, W.P.A. Marketing Laws Survey, id. Nos. Io and II.

' E.g., N. C. Laws 1937 , c. $127, \$ 121(\mathrm{e})$, exacting an annual privilege tax of \$250 from: "Every person, firm or corporation, not being a regular retail merchant in the State of North Carolina, who shall display samples, goods, wares, or merchandise in any hotel room, or in any house rented or occupied temporarily, for the purpose of securing orders for the retail sale of such goods, wares, or merchandise so displayed. . . " This statute was recently declared invalid by the unanimous decision of the U. S. Supreme Court in Best and Co. v. Maxwell, 3 II U. S. 454 (1940).

'E.g., Idaho Laws I937, c. 226: "Fruit sold in state must show place of origin." A wide degree of discrimination between local and out-of-state fruit is possible under this type of statute. CaL. AGRIC. CODE $\$ \$ 781-831$ "... establishes minimum standards of grades and containers for specified fruits and vegetables. Unlawful to ship or sell non-conforming goods: inspection fee to be paid by owner."

"Thus an itinerant trucker in Washington is subjected to a license of $\$ 300$ per vehicle by each county through which the vehicle may pass. Wast. REv. STAT. (Remington, I932) \$\$8353-8355. Neb. Comp. Stats. (Supp. I939) \$\$66-427, 66-805 require the Department of Agriculture and In- 
create trade barriers by virtue of unfair and discriminatory administrative practices. Virtually any law may be administered in favor of local enterprise if administrative agencies, which often enjoy discretionary authority, elect to take a partisan slant in the framing of rules and orders; consequently, no example is cited. ${ }^{6}$

Each of the classes of trade barrier laws enumerated above has been enacted and is administered under one of three sovereign state powers. ${ }^{7}$ First is the power of taxation. This category may be subdivided into the following three parts: $(I)$ taxes which are levied to exclude out-of-state products or services in favor of the products or services of a home enterprise; (2) taxes levied to eliminate or curb a competitive type of merchandising; (3) taxes which, because of their multiplicity when encountered in interstate commerce, have a cumulative barrier effect. Second, is the police power exercisable for the protection of the public health, safety, morals, and welfare, including the powers to inspect, quarantine, and embargo animals, plants, and other products moving in interstate commerce. Third, is the power inherent in a state through its proprietary interest in its own natural resources.

It should be emphasized at this point that there is no intent herein to criticize the states for properly exercising these powers. The dangers lie in the abuse of these powers by pressure groups to achieve interstate market restrictions. These abuses do not make state sovereignty more secure; rather they tend to impair it. Increased demands for relief, by those discriminated against, are made upon the Federal Government with the appearance of each new trade barrier situation. The cumulative effect of these demands may yet become the motivating influence producing a greater degree of federal control. A prompt and adequate solution of this question by the states themselves would nullify the possibility.

\section{Historical Background ${ }^{8}$}

During the pre-Revolutionary days the colonists struggled with many economic problems, not the least of which was that of the regulation of trade among them-

spection to designate highways and establish registration offices for inspection and registration of motor vehicle fuels transported in large quantities. Any truck with tank capacity of more than 20 gallons must stop at a registration office and pay tax on fuel in excess of 20 gallons.

- No studies of administrative orders, rules and regulations issued under various statutes have been made. Sampling by the W.P.A. Marketing Laws Survey indicates the existence of an enormous amount of this type of control. For example, a bundle containing only single copies of orders affecting marketing from the state of Illinois alone, issued by ten agencies in that state, weighed 282 pounds. Bane, Administrative Marketing Barriers, infra this issue, gives typical illustrations of barriers effectuated by administrative action.

${ }^{7}$ See note 2, supra.

${ }^{8}$ See Bogart, Economic History of the United States (ed. I938) Pt. 1; Van Metre, Economic History of the UNTtEd States (ed. 1921) Pt. 2; FAUlkNer, Economic Fistory of the United States (ed. I928) cc. I, 2, 3; Clark, History of Manufactures in the United States (1929); Bidwell and Falconer, History of Agrictlture in Northern United States, 1620-I860 (1925); Bruce, Economic History of Virginia in the ifth Century (1935); Day, History of Commerce IN the United States (1925); Johnson et al., History of Domestic and Foreign Commerce op the United States (igi5); Janeson, The American Revolution Considered as a Social Movement (Ig26); Dewey, Financial History of the United States (12th ed. 1934); Beard, An Economic Interpretation of the Constitution of the United States (1913); Fiske, The Critical Period in AMerican History (IgOI); Story, Commentaries on the Constitution (1833) \$5259-261; The Federalist, No. XIII (1788) 5; Madison, Introduction, in Elltort, Debates (1827) 109-22; Hacker, 
selves. ${ }^{9}$ Domestic commercial problems became intensified with the growth of the colonies and through the Revolutionary period. In 5783 , George Washington, in a circular letter to the states, urged "the prevalence of that pacific and friendly disposition among the people of the Union, which will influence them to forget their local prejudices and policies; to make those mutual concessions which are requisite to the general prosperity; and, in some instances, to sacrifice their individual advantages to the interest of the community."10

The ties that bound the states together immediately following the Revolutionary War were tenuous and inadequate. It was all too evident within the next six years that Washington's advice was not to be taken. It appeared that the newly formed Union would soon become a series of disunited and unorganized states, each easy prey for larger world powers. No really strong sentiment had matured favoring the Union; there was, instead, much opinion in favor of local self-government. Much of this feeling stemmed from commercial rivalry between the states, as was ably set forth by Madison, ${ }^{11}$ and caused concern to the thoughtful men of that day. ${ }^{12}$ It was clear to the delegates to the Annapolis Commercial Convention ${ }^{13}$ in 1786 and to those of the Philadelphia meeting the following year that ways and means must be found to reduce the friction between the states, and to control more satisfactorily domestic commerce. ${ }^{14}$

The record shows that every plan put forward at the Philadelphia Convention included a wide grant of power to the Federal Government to regulate interstate commerce. No serious objection was raised to the commerce clause as it finally took shape." It provides that Congress shall have power "To regulate commerce

The First American Revolution (Sept. I935) 27 CoL. UnIv. QuAR. 257. Also, these texts contain extensive bibliographies, appended chapter by chapter, which will be of value to those desiring a more detailed historical background.

${ }^{\circ}$ Mr. Justice Catron in the Passenger Cases, 7 How. 283, 445 (1849), said: "Before the Constitution existed the states taxed the commerce and intercourse of each other. This was the leading cause of abandoning the confederation and forming the Constitution-more than all other causes it led to the result."

${ }^{20} 26$ Fitzpatrick, The Writings of George Washington from Original Manuscripts Sources, $1745-1799$ (1938) 487 .

${ }^{11}$ Madison, Preface to the Debates in the Convention of 1787 , in 3 Farrand, Records OF THE FED. eral Convention of I787 (I927) 547 .

${ }^{22}$ See I BAncroft, History of THE Constitution (1883) 334, for an expression of this concern.

${ }^{18}$ This Convention was called to "take into consideration the trade of the United States; to examine the relative situation and trade of the said states; to consider how far a uniform system in their commercial relations (might) be necessary to their common interest and their permanent harmony; and to report to the several states such an act relative to (that) great object, as when unanimously ratified by them (would) cnable the United States in Congress assembled effectually to provide for same." Elliott, DeBates (1827) ri5-116.

14 As might have been expected, the states were not unanimous in their efforts to improve current conditions. Rhode Island, often called "Rogues" Island, an active participant in commercial fights, failed to participate in the Constitutional Convention of 1787 , a fact which significantly indicates the importance the Convention attached to trade barrier activities. Madison said "Rhode Island was the only exception to a compliance with the recommendation from Annapolis, well known to have been swayed by an obdurate adherence to an advantage which her position gave her of taxing her neighbors through their consumption of imported supplies, an advantage which it was foreseen would be taken from her by a revisal of the Articles of Confederation." 3 FARRand, op. cit. supra note II, at 546

${ }^{25}$ Schuyler, The Constitution of the United States (1923) is. 
with foreign nations, and among the several states and with the Indian Tribes."10 This provision is the constitutional guarantee of free trade among the states. ${ }^{17}$

The first serious recession from the principle of domestic free trade grew out of the fraud and adulteration in food products which became rampant after the War Between the States. Business ethics, following the war, reached a low ebb and it is perhaps not surprising, considering the abuses of that time, and in the absence of federal regulation, that the states sought to control certain commercial malpractices by enacting stringent tax laws. The first oleomargarine tax laws are in point.

In addition to regulation to combat fraudulent practices, the growing irregularity of legitimate marketing processes in itself warranted governmental regulation. Weights, measures, quality standards from Maine to California required policing. In addition quarantines were needed to eradicate or control the spread of animal and plant diseases.

However, coupled with the need for and appearance of numerous trade regulations there emerged two dangers. One was that the sheer multiplicity and complexity of these regulations might unintentionally hamper trade. This has happened. The other was that a trend might develop to use such measures to erect barriers against competitors, while at the same time providing a benefit to local enterprises. This too has happened, and these happenings have engendered hostility and animosity between the states on different issues. Retaliatory barrier legislation has been enacted, confusion has resulted, and consumers have been penalized to such an extent that today trade barriers are a threat to the welfare of the nation.

\section{Present Extent of Interstate Trade Barriers}

In the last two decades the growth of trade barrier laws and regulations has "passed beyond the stage of mere curiosa into the socially, economically, and politically dangerous realm of local autarky."18 The depression starting late in 1929 dealt severe blows to state financial programs in two ways. There occurred a drastic reduction in taxable values and tax receipts, accompanied by a markedly increased demand for the expenditure of public funds. Slack business, widespread unemployment, and declining tax revenues faced the state legislatures in the early thirties. Thus the stage was set for the appearance of the majority of the present laws, rules and regulations characterized as trade barriers. ${ }^{19}$

${ }^{20}$ Consr., Art. I, \$8, clause 3. Two other provisions having a bearing on trade regulation were included in the Constitution. They are Art. I, \$9, cl. 6, prohibiting Congress from preferring the ports of one state to those of another; Art. I, \$ro, cl. 2, prohibiting a state, "without the consent of Congress, from laying any imposts or duties on imports or exports, except that which may be absolutely necessary for executing its inspection laws. ..." However, following the implications to the contrary of Chief Justice Marshall in Brown v. Maryland, I2 Wheat. 419 (U. S. 1827), the Supreme Court has since ruled in Woodruff v. Parham, 8 Wall. 123 (U. S. I869); Pittsburgh Coal Co. v. Louisiana, 156 U. S. 590 (1895); Patapsca Guano Co. v. Board of Agriculture, 17I U. S. 345 (1898), that these clauses refer only to foreign commerce.

${ }^{17} \mathrm{Sec}$, for instance, the unequivocal declaration of Mr. Justice Roberts in Milk Control Board v. Eisenberg Farm Products, 306 U. S. 346, 35I (1939), and that of Mr. Justice Hughes in the Minnesota Rate Cases, 230 U. S. 352, 398 (19r3).

${ }^{18}$ The Economist, London, Sept. 23, 1940.

${ }^{10}$ As put by Buell, Death by Tariff (Aug. I938) 18 Forrone 32: "the principle fundamental to prosperity is now being violated; protectionism turning inward has been involed by state against state, industry against industry." 
The amazing growth of trade barriers during the early thirties was noted occasionally by students ${ }^{20}$ and writers. ${ }^{21}$ It remained, however, for Governor Allred of Texas to focus the attention of the Council of State Governments ${ }^{22}$ on this menace early in 1937. The Council adopted the trade barrier problem as a part of its national program in 1938 . Their first step was to call a national trade barrier conference in Chicago in April, 1939..$^{23}$ To provide the basic material for this conference the Council requested the Marketing Laws Survey of the Works Progress Administration to extract from its current study on Entry Into Business a tabulation of state laws creating or tending to create trade barriers among the states. The Survey prepared charts of their findings, which were later published, ${ }^{24}$ showing extracts from state laws in the following categories: motor vehicles, 301 examples; dairy products, 209; oleomargarine, 245; livestock and general foods, $13^{8}$; nursery stock, I45; liquor, I25; use taxes, rog; general preference, II3; commercial fishing, 35 ; and insurance, 69 examples. This tabulation totals 1,489 state laws.

At the joint request of the Council and the Interdepartmental Committee, ${ }^{25}$ the Marketing Laws Survey later prepared a digest of trade barrier laws for the nine states whose legislatures met in 1940 . This digest covered the additional categories of chain stores and transient merchants, including a chart on reciprocity. It has been estimated that the final classification will show over 3,000 trade barrier laws now on the statute books of the $4^{8}$ states.

It is encouraging to note that since the $x 939$ National Conference few new trade barrier laws have been passed. However, few have been repealed. The problem of solving permanently the trade barrier question divides into these two parts, namely, prevention of the passage of new barrier laws and revision of the great bulk of present laws to remove barrier features.

Trade barrier laws are widely spread over the country according to the economic interests of a state or group of states. Consider margarine taxes and license fees, for example. On margarine made from domestic fats and oils only, ten states impose a manufacturer's annual license fee of from $\$ 5.00$ to $\$ \mathrm{r}, 000$, fourteen states impose a wholesaler's annual license fee of from $\$ 3.00$ to $\$ 500$, thirteen states impose an annual retailer's license fee ranging from $\$ \mathrm{r} .00$ to $\$ 400$, nine states impose a tax on all margarine sold of from 5 to I5 cents per pound. Wyoming, Nebraska and Minnesota, cattle-producing states, tax at from to to 15 cents per pound all margarine sold within their borders made from other than animal fats. Further, when margarine is made from imported fats and oils, additional states levy restrictive taxes and fees. ${ }^{26}$ State preference laws are also widespread. All states except Alabama

20 Notable is Melder, State and Local Barriers to Interstate Commerce (I937).

${ }^{21} \mathrm{~A}$ bibliography is available upon request from the U. S. Bureau of Foreign and Domestic Commerce.

${ }^{22}$ For history, organization, program, and achievements of the Council of State Governments, see The Flandbook of the States (I940).

${ }^{23}$ For a complete record see Proc. Nat. Conf. on Interstate Trade Barriers (Council of State Gov'ts, 1939).

2 Comparative Charts of State Statutes Illustrating Barriers to Trade Between the States (W.P.A. Marketing Laws Survey, 1939).

${ }^{25}$ See note 46 , infra.

${ }^{20}$ Testimony of Charles H. Janssen and John R. Moloney, 12 T. N. E. C. Hearings, supra note I, No. II, at 305-321. 
have one or more forms of preference laws requiring the use of local stone, coal, printing, equipment, clothing, farm products, and labor for state purposes.

The variety in motor truck regulation is striking. ${ }^{27}$ There are ten single unit length requirements in the 48 states for a 6-wheel tractor and trailer, only 19 states having a common standard. Weight requirements for this type equipment vary from "not specified" to 44,000 pounds, there being 22 different requirements. Ten states, in this particular, have a common standard, but no two are adjacent. Pay load limits vary from the Texas maximum of 7,000 pounds, if destination is other than a rail head, or I4,000 pounds if destination is rail head, to 78,000 pounds in New York. Gross load requirements vary from 18,000 in Kentucky to 120,000 pounds in Rhode Island.

Barriers are equally evident in the field of agricultural inspection and quarantine. All states exercise this power in some fashion. ${ }^{28}$ Twenty-six states require out-of-state nursery stock dealers to register and to buy a license. In one state the quarantine authority may bar out-of-state products when the domestic supply is sufficient for home needs. ${ }^{29}$ Thirty states provide for inspection upon entry of products into the importing state. In this field the non-uniformity of state requirements relating to duplicate invoices, special state and special commodity tags, permits, dealers' and agents' fees, registration fees and bonds constitutes a cumulative trade barrier of great magnitude. ${ }^{30}$ The penalty for violation of these multitudinous restrictions may be revocation of license, confiscation of property, or excessive terminal inspections, with a consequent loss of merchandise.

Space limitations do not permit an exhaustive survey of the present extent of the trade barrier movement in each classification in which barriers have been noted; however, the examples quoted may be considered fairly typical of those found in other classes.

\section{ECONOMIC IMPLICATTONS}

It is unfortunate that no complete and thorough-going analyses have been made of the economic effects of trade barriers. The newness of the issue and the magnitude of expected difficulties thus far constitute practical deterrents to those interested in developing such data. Students have been forced to make deductions based on individual cases and to generalize along the lines of orthodox economic theory. However, from practical observations, we know that trade barrier restrictions force the movement of goods and services through artificial channels. As a consequence costs are increased and eventually a rise in price follows, or at best future price reductions are made less likely. These effects, sometimes arising in narrow areas, are often hard to discover as they become diffused throughout the domestic economy.

${ }^{27}$ See chart on this subject cited in note 24 , stspra.

${ }^{28}$ Testimony of R. P. White and Carl C. Lumry, 12 T. N. E. C. Hearings, supra note 1, No. 12, at $357-365$.

${ }^{20}$ I.e., Georgia's 1935 law authorizing the Commissioner of Agriculture to embargo out-of-state fruit and vegetables when local supplies are ample. Ga. Laws 1935, p. 371 .

${ }^{30} \mathrm{McClain}$ and White, Plant Quarantines as Trade Barriers (Amer. Ass'n Nurserymen, 1940). 
They are nonetheless serious. In certain cases they may be traced with comparative ease. For example, the effect of the Kentucky 18,000 pound load law on operating costs is clear from the testimony before the Temporary National Economic Committee at the trade barrier hearings. ${ }^{31}$ Shippers of leather between Chicago, Illinois, and Middlesboro, Kentucky, were forced to reload shipments from one to two vehicles at Louisville. Aside from the not inconsiderable delay and added terminal costs, actual freight rate costs were increased approximately 50 percent over a single vehicle operation. This increase must be paid by the shipper and added to the cost of the merchandise.

The dairy industry affords many examples of the economic effects of trade barriers. Farmers producing at low cost in Indiana cannot sell their cream in New York City and Washington, D. C., markets on account of numerous inspection requirements. This situation benefits neither the midwestern producer nor the eastern consumer. Prices paid to the Indiana farmer are low. Prices paid by the eastern consumer are higher than they would be in a competitive market. ${ }^{32}$

In general, it can be said that trade barriers tend to lower the standard of living. This is illustrated by the excise taxes and license fees imposed on oleomargarine. The magnitude of these costs to the producers and sellers of this commodity is sufficient to shut it entirely out of some states and to reduce sales in others. ${ }^{33} \mathrm{Re}$ strictions thus contrived are doubly depressing on living standards since they bear more heavily on the lower income groups. Figures compiled by the U. S. Bureau of Home Economics ${ }^{34}$ show that the lower the income of a family the less butter they buy. A family with a weekly expenditure amounting to from $\$ 4.00$ to $\$ 4.99$ per adult or adult equivalent buys about 40 pounds of butter per year per adult or adult equivalent and practically no margarine. A family similarly classified with a weekly expenditure of from $\$ \mathrm{r} .33$ to $\$ 2.00$ buys only I2 pounds of butter per year and over 8 pounds of other table fats including margarine. It is evident, therefore, that any tax on margarine falls largely on the low income group. Further, the total consumption of margarine is reduced by these restrictions since the product would sell for considerably less in certain markets were it not so heavily taxed. Any degree of underconsumption in margarine serves to reduce the domestic market for oils, imported and domestic, animal and vegetable, with a consequent detriment to American farmers.

${ }^{31}$ Testimony of John V. Lawrence, 22 T.N.E. C. Hearings, supra note I, No. I4, at 422. Further data may be found in Investigation and Suspension Docket No. M-404, I 8 I. C. C. (Motor Carrier) 265 (1939).

${ }_{33}$ Testimony of Messrs. Ruehe, Treadway, Money, Witham, Freeman and Creighton, 12 T. N. E. C. Hearings, supra note $\mathrm{I}$, No. 12, at 34ז-357. Also testimony of Mrs. Beatrice A. Schalet, id. No. 13: at $381-384$.

${ }^{33}$ Testimony of Charles A. Janssen and John R. Moloney, id. No. II, at 305-32I; also Truitt. Interstate Trade Barriers and the Cotton Industry (address before the Cotton Research Congress, June 1940).

${ }^{36}$ Steibling and Phipard, Diets of Families of Employed Wage Eearners and Clerical Workers in Cities, U. S. Dep't Agric., Circular No. 507 (Jan. 1939); How W.P.A. Wages Are Spent (April 1940) 50 MONTHLY LABOR REv, 929. 
Convincing evidence of the uneconomic character of certain trade barrier laws may be seen in the arguments of their proponents. Many such cases are on record where they clearly state that a law should be passed to provide protection from domestic competition. ${ }^{35}$ It is interesting to note that where the public has been

${ }^{85}$ E.g.

"Whereas, oleomargine is sold in direct competition to butter; and

"Whereas, the prosperity of the farmer depends upon the price he gets for his product; and

"Whereas, the prosperity of the merchants and meat markets depend on the prosperity of the farmers; therefore be it

"Resolved, that we, the undersigned farmers and dairymen sespectully petition the merchants and meat markets of Polk County, Wisconsin, to discontinue the sale of butter substitutes.

"Be it further resolved, that we urge all our citizens to use their best influence to eliminate butter substitutes from Polk County, inasmuch as they are only food substitutes, and are injurious to public health, and our Polk County citizens' prosperity depends upon the dairy industry." Wisconsin Cooperative Creamery Ass'n, May 31, I921. See J. S. Abbott Bull. No. 12, March 1928, Munsey Bldg., Washington, D. C.

"Resolved, that we favor legislation against the manufacture and sale of any substitutes for dairy products, believing that the manufacture and sale of such products to be detrimental to the health of the public as well as harmful to the dairy industry.

"Resolved, that we endorse the continued good work of the National Dairy Union in protecting the dairy interests relative to the sale of substitutes for butter." Nat. Creamery Buttermakers Ass'n annual convention, 1923. Printed in Butter, Cheese and Egg Journal, Nov. 14, 1924.

"We are opposed to any changes in the present federal oleomargarine law until it can be shown that a better law can be enacted to prevent fraud and deception in the sale of this product." Hoard's Dairyman, Oct. 5, 1938.

"In I935 the National Cooperative Milk Producers Federation petitioned the Congress to enact three types of legislation:

"x. A new federal tax of five cents a pound on all oleomargarine.

"2. The equivalent of an import, excise or processing tax of at least five cents per pound on all imported fats and oils used in the United States.

"3. A federal law to prohibit the use of interstate commerce to nullify state oleomargarine taxes." Pabst, Butrer and Oleomargarine (I937) 85. Also Oleomargarine, Hearing before Subcommittee on Agriculture on H. R. 5586 and H. R. 5587, 74th Cong., Ist Sess. (x935) 181.

The interest of the dairy industry in protecting the public by prohibiting or by restricting the sale of products they believe to be detrimental to the public as well as harmful to the dairy industry, in the case of oleomargarine does not seem to be well founded. A comparison of the violations of the Pure Food and Drugs Act of 1906 between butter court eases and oleomargarine court cases fails to support the contentions of the dairy interests. The following table, showing the court record of the two industries, is compiled from Notices of Judgment (Bull. issued by the U. S. Food and Drug Adm'n). The name of the defender and the nature of the violation, there given, are omitted here.

\begin{tabular}{|c|c|c|c|c|c|c|}
\hline Fiscal Years & But & Court Cases & & Margari & te Court & \\
\hline Ending June & Prosecutions & Seizures & Total & Prosecutions & Seizures & Total \\
\hline 1925 & $\ldots \ldots \ldots \ldots \ldots \ldots 85$ & I88 & 273 & o & $\mathbf{x}$ & I \\
\hline 1926 & $\ldots \ldots \ldots \ldots \ldots \ldots \ldots$ & 143 & 202 & I & 3 & 4 \\
\hline 1927 & $\ldots \ldots \ldots \ldots \ldots \ldots \ldots 24$ & 79 & 103 & $\mathbf{0}$ & 3 & 3 \\
\hline 1928 & $\ldots \ldots \ldots \ldots \ldots \ldots \ldots \quad 54$ & I04 & $15^{8}$ & 0 & $\mathbf{I}$ & $\mathbf{I}$ \\
\hline 1929 & $\ldots \ldots \ldots \ldots \ldots \ldots \ldots 22$ & 98 & 120 & $\mathbf{0}$ & I & $\mathbf{I}$ \\
\hline Calendar Yea & & & & & & \\
\hline 1930 & $\ldots \ldots \ldots \ldots \ldots \ldots \ldots$ & & 148 & & & 0 \\
\hline I93I & $\ldots \ldots \ldots \ldots \ldots \ldots \ldots$ & & 172 & & & 2 \\
\hline 1932 & $\ldots \ldots \ldots \ldots \ldots \ldots \cdots$ & & 154 & & & o \\
\hline r933 & $\ldots \ldots \ldots \ldots \ldots \ldots \ldots$ & & 187 & & & $\mathbf{I}$ \\
\hline x934 & $\ldots \ldots \ldots \ldots \ldots \ldots$ & & 464 & & & 0 \\
\hline 1935 & $\ldots \ldots \ldots \ldots \ldots \ldots \ldots$ & & 263 & & & $\mathbf{0}$ \\
\hline 1936 & $\ldots \ldots \ldots \ldots \ldots \ldots$ & & 140 & & & $\underline{1}$ \\
\hline & Total .......... & & 2,384 & & & $x_{4}$ \\
\hline
\end{tabular}


permitted a referendum, it has rejected tax laws which would have created serious trade barriers. ${ }^{36}$

Trade wars between states, while having marked uneconomic aspects, often are accompanied by very undesirable results of a social or political ${ }^{37}$ nature. Sectional bitterness is created which is hard to eradicate. In the opinion of many students this particular factor on the continent of Europe played an important part in precipitating the present European economic and democratic breakdown. ${ }^{38} \mathrm{We}$ are not free from such controversies in the United States; the controversy between the dairy and cotton states over the repeal of the margarine taxes is a case in point. ${ }^{39}$ Such bickerings do not contribute to greater national unity. Former Governor Starks' phrase, "The Balkanization of the United States," is not idle verbiage.

During the years from 1925 to 1936 the production ratio between creamery butter and margarine varied between 5 to $I$ and 7 to $I$; hence the butter industry with a volume of from 5 to 7 times that of the margarine industry was in court at least 15 times to the margarine industry's once.

II

"The session of the Legislature of Kentucky, which closed on March I4, wisely declined to enact legislation proposed to increase the size and weight of trucks permitted on the highways of that State. -. . The Kentucky Railroad Association, and the railroad brotherhoods, along with the individual efforts of railroad officers and employees, helped to arouse many newspapers, county judges, various civic and commercial organizations, the operators of ordinary automobiles and small trucks, and the public in general, to the evils which an increase in the loads permitted on the highways would bring about. . . Admittedly, railroad employees had a legitimate interest in opposing truckers who were diverting business from the railroads and thus depriving railroad men of cmployment. . . . This message, therefore, is to point out the successful result of cooperation between railroad employees and management, where they can agree upon a common purpose. ..." President's Message No. 6r (April 1940) 16 L. \& N. EMPloyees' MAG. No. 4.

For further typical activity see Investigation of Railroads, Holding Companies and Affiliated Companies, Hearings before a Subcommittee of the Senate Committee on Interstate Commerce, 75th Cong., 2d Sess. (1937) Pt. 23, at 1016I-10215.

III

"Behind the move to repeal the city's . . . license ordinance which operates . . . as a tariff against itinerant ... merchants is the smoldering threat of a trade war. . . .

"Local dealers ... fear nearby cities ... may pass reprisal ordinances . . . repeal would throw the market wide open . . . depriving local dealers who pay local taxes, of trade. . . Indianapolis Times, Oct. 26, 1940, quoted in Sikes and Parrish, Municipal Trade Barriers (I940) 16 IND. L. J. 220. Extracts of actual clippings from newspapers, trade journals and periodicals, showing similar trade-barrier motives behind nuisance ordinance legislation, are to be found with the testimony of J. M. George, Nat. Ass'n of Direct Selling Cos., Winona, Minn., I2 T. N. E. C. Hearings, supra note 1 , No. 13, at 384 .

${ }^{30}$ Oregon has four times rejected margarine tax laws upon referendum, as follows: Nov. 1920, by I19,126 to 67,101; Nov. 1924, by 157,324 to 91,597; Nov, 1932, by 200,496 to 131,273; and Nov. 1936 , by 114,524 to 66,880 . California has done likewise twice, in Nov. 1926 and Nov. 1936, the latter time by $1,359,096$ to 345,470 .

${ }^{87}$ In one state two candidates for office of sheriff ran for reelection on a platform of non-enforcement of the state's motor vehicle laws. SEN. Doc. No. 152, 73d Cong., 2d Sess. (1934) I95 n.

${ }^{38}$ See Kunstenaar, Internal Marketing Barriers in Europe: Pre-Hitler Austria as an Outstanding Example, infra this issue; testimony, Dr. F. Eugene Melder, Clark University, i2 T. N. E. C. Hearings, supra note I, No. II, at 273-28I; Furth, Address before the American Marketing Association, Dec. 27, 1939.

${ }^{30}$ See Wis. Joint Res. No. 84, Wis. Laws 1939, p. I03r, adopted in an effort to placate southern states whose cottonseed oil, made into margarine, is virtually shut out of Wisconsin. "Wisconsin's olcomargarine tax law has decreased the consumption of the product in that State from 10,000,000 pounds per year to about 5,000 pounds." J. Comm., Oct. 15, 1940, quoting Wisconsin's Progressive candidate for governor. 


\section{TRENDS In Solutions}

The very nature of the trade barrier question makes mandatory a consideration of the existing powers of various branches of the Federal Government to effect its solution. For a considerable period the Supreme Court has enunciated applicable principles by which state legislatures might be guided. While it is recognized that generalities do not solve specific cases, broad guiding criteria are useful. By the exercise of the "police" powers the states cannot impose burdens on interstate commerce which are "direct." field, however, regulations of the states may, in fact, burden interstate commerce even though such burden may not be designated as "direct" by the courts. Yet in cases where discrimination against interstate ${ }^{41}$ or foreign ${ }^{42}$ commerce is obvious on the face of the state law, it will not be upheld by the Supreme Court. It is clear that the court will look into the facts of each case to determine the extent to which the statutory provision at bar operates as a burden on interstate commerce. This procedure is best illustrated in McCarroll $\nu$. Dixie Greyhound Lines ${ }^{43}$ in which the Court used arithmetical calculations to show the mischief of the Arkansas statute.

The dissenters in the McCarroll case ${ }^{44}$ took occasion in their opinion to emphasize that the regulation of interstate commerce was primarily the duty of Congress. When Congress chooses to act, because its power over interstate commerce is plenary, all conflicting state laws must give way. Nevertheless, as has been pointed out by many students, Congress has not assumed comprehensive jurisdiction in this area. It may be argued that, owing to the great climatic and geographic variations in the United States, complicated further by variations in urbanization and industrialization, the maximum degree of centralized control by Congress possible under the Constitution would be so laden with administrative difficulties as to be impractical. Such arguments, however, should not blind public officials to the detrimental effect of trade barriers on the national domestic economy. Trade barriers should weigh upon Congress in direct ratio to their burden upon interstate commerce.

Following the trade barrier hearings before the Temporary National Economic Committee, ${ }^{45}$ the Interdepartmental Committee ${ }^{46}$ decided that the next logical step in any remedial program would be an examination of the present federal statutes to "determine how far such legislation can be used either directly to set aside or indirectly to influence the modification of state laws and local ordinances which are barriers to trade." This task was assigned to an eleven member Legal Subcommittee

\footnotetext{
10 This well accepted constitutional doctrine is forcefully set forth by Mr. Justice Cardozo in Baldwin v. Seelig, 294 U. S. 51 I, 522 (I935).

"2 Hale v. Bimco Trading Co., Inc., 306 U. S. 375 (1939).

${ }^{43} 309$ U. S. I76 (1940).

${ }^{45}$ Reported in 12 T. N. E. C. Hearings, supra note 1, Nos. I0-15. The Committee examined 29 witnesses of divergent background, covering various phases of the interstate trade barrier problem.

${ }^{40}$ The Interdepartmental Committee on Interstate Trade Barriers is an informal voluntary group, formed upon the suggestion of former Secretary of Commerce Hopkins to act as a clearing house and coordinating group in the trade barrier field. Representatives from the following agencies compose this Committee: U. S. Dep'ts of Commerce, Labor, Justice, State, Treas., Agric., the U. S. Tariff Comm., I. C. C., Fed. Works Agency, and the Consumer Counsel Div. of the Dep't of Agric.
} 
set up for this purpose. In presenting the following list of administrative actions which, in the opinion of the Subcommittee, could possibly be taken to combat interstate trade barriers, it must be emphasized that the Subcommittee was not concerned with matters of policy or expediency. The Subcommittee attempted to discover power. It did not attempt to pass judgment on the wisdom of using such power.

Through the cooperative action of interested federal agencies, the Interdepartmental Committee on Interstate Trade Barriers and the Council of State Governments, considerable persuasive pressure could be exerted in forestalling the enactment of trade barrier legislation and in combating trade barrier legislation which has been enacted.

State and local laws may, on their faces, constitute a restraint on interstate trade or they may sanction administrative action which can be used to this end. Also, state or municipal officers. may act ultra vires to suppress or restrain interstate commerce. The filing of briefs amicus curiae by the Department of Justice, injunction suits under the theory of the Debs case, ${ }^{47}$ and anti-trust prosecutions are techniques which may be effective in combating these restraints of trade practices.

Concerted policy on the part of federal agencies, of bringing cases before the United States Supreme Court which would clarify and possibly broaden the existing judicial concept of interstate commerce, might materially aid litigants who are burdened by trade-restricting state laws.

The Federal Trade Commission is empowered to undertake an investigation of interstate trade barrier problems.

A uniform seed law is now being prepared by the Department of Agriculture, while the standard milk ordinance of the Public Health Service has been adopted by many communities. The Interdepartmental Committee on Interstate Trade Barriers might effectively assist in advancing this type of administrative action.

The Surgeon General may call special conferences of state health boards and of state health officers. Moreover, he is authorized to detail personnel to cooperate in activities such as are being carried out by the Interdepartmental Committee.

Under the Federal Food, Drug and Cosmetic Act, the existence of trade barriers with respect to any commodity might well be taken under consideration in prescribing regulations. In this connection, reference is made to state labeling laws, to state laws specifying sizes of containers and to state laws governing the quality of milk and cream. Moreover, it is believed that administrative action publicizing the situations in which barriers to interstate shipments have developed in this field might be possible under this federal legislation.

Under the Agricultural Marketing Agreement Act of 1937, it is believed that the Secretary of Agriculture has sufficient discretion in setting up administrative conditions precedent to needed federal cooperative action to require that state reg-

${ }^{47}$ In re Debs, 158 U. S. 564 (1895). 
ulations relative to state marketing agreements with respect to milk and its products be promulgated with a view toward eliminating trade barriers.

Under Section 3 of the Animal Industry Act, the Secretary of Agriculture is authorized to cooperate in execution and enforcement of provisions of the act working toward the suppression of dangerous, contagious, infectious, and communicable animal diseases. It would appear that, pursuant to the authority contained in the statute, he could, through the exercise of authorized discretion in formulating or approving plans and methods for combating contagious animal diseases, exert economic measures which might be successful in eliminating the trade barrier aspects of animal quarantines. ${ }^{48}$

As a general proposition it would seem that whenever a specific trade barrier exists in the states, the operation of which materially interferes with or hampers a project financed in whole or in part by federal appropriations, those administering the expenditure and the granting of such funds may attach conditions that will operate to remove the objectionable trade barrier.

With particular reference to trade barriers, the states have been cooperating among themselves quite effectively during the past two years. ${ }^{49}$ These efforts have resulted in a practical halt in the trend toward more barrier laws. In the main, the job now confronting the states is one of legislative revision to eliminate barrier provisions from the large body of present state law which has been thus classified.50 Much of this law should be revised on a more uniform basis. This is especially true of the motor regulatory laws, from which it is necessary to remove requirements that impose a cumulative burden on interstate commerce.

For the past 50 years the states have kept the Conference on Uniform Laws in existence and functioning. $U_{p}$ to the present time the Conference has approved 70 uniform acts which have been adopted by the various states, ranging from 35 in South Dakota to 3 in Texas. Broadly, the efforts of the Conference are directed toward removing friction between the states, preserving the independence of the states, and at the same time making our dual system of state and federal government function more smoothly. The Conference recently joined forces with the Council of State Governments in order more effectively to focus their efforts on their fifty-year goal of bringing about greater uniformity in state law. Although the results of this group have been worth while, ${ }^{51}$ it has not yet been active on the trade barrier question.

The use of interstate compacts has long been available to the states in solving mutual trade problems. The effectiveness of this intergovernmental device as a

\footnotetext{
${ }^{8}$ A Stsmmarized Report of the Legal Subcommittee of the Interdepartmental Committee on Interstate Trade Barriers, giving the subcommittee's conclusions in greater detail, is available without cost from the U. S. Dep't of Commerce.

${ }^{40}$ For detailed evidence consult the source books referred to in notes 22 and 23 , stipra.

to The classification of the Marketing Laws Survey is cited note 24, supra.

${ }^{61}$ Saeta, Unified Legislation Cited as Goal of Conference on Uniform State Laws (Dec. 1940) Is CaL. State B. J. 359; and Uniform State Latv Group and the Council of State Governments Join Forces (Aug. I940) $x_{3}$ StATE Gov. 153, 3rd cover.
} 
method of eliminating trade barriers is yet to be proved. Pacts have recently been completed in the fields of crime control, water resources, oil conservation, tobacco regulations, and park, bridge, and transportation authorities. A large portion of the total compacts now in force deals with boundary and jurisdictional adjustments, harbor problems, water resources, and engineering projects. Only a very few deal with economic or trade questions. ${ }^{52}$

From the variety of suggestions, proposals and counter-proposals for the solution of the trade barrier problem, a line of likely successful attack seems to emergeand that is a cooperative effort between the Federal Government and the states. It seems probable that the Court will make short work of such flagrant and outstanding barrier cases as may come before it, but to everyday use of the judicial procedure there are the practical limitations of time and expense involved in long litigation. Congress may or may not, subject to the exigencies of the day, undertake a more complete and thorough-going regulation of interstate commerce in areas now infested with trade barrier practices. And action by the states alone has inevitable limitations.

A joint approach, however, would seem to obviate many of the disadvantages inherent in an approach relying wholly on the courts, the Congress, the Federal Government, or the states, acting separately. It is apparent that the complicated task of commercial regulation, because of its relationship to individual livelihoods, demands sensitive treatment. Legislation affecting such interests should be enacted only upon the facts established by thorough economic and legal research and after consideration of all interests involved. The collective guidance and experience of representatives of both federal and state governments seem required for this purpose.

At the trade barrier hearings before the Temporary National Economic Committee the Executive Director of the Council of State Governments proposed that Congress create a joint federal-state committee. ${ }^{53}$ The Temporary National Economic Committee, in its Final Report, ${ }^{54}$ has recommended such a committee; moreover, former Secretary of Agriculture Wallace ${ }^{55}$ earlier publicly endorsed the prosopal. Representatives of state governments meeting in Washington in the Fifth General Assembly of the Council of State Governments reaffirmed their stand against trade barriers. Resolutions were adopted which, if zealously followed by the states, will go far towards permanently curing this trouble. ${ }^{56}$ At the present time attention is

${ }^{52}$ Recent Development in Interstate Compacts, in THE Boor of THE STATEs (r939-1940) adapted from Dodd, Interstate Compacts (1939) 73 U. S. L. REv. 75, 86-88, 124-127; Routt, Interstate Compacts and Administrative Cooperation (Jan. 1940) 207 AnNals 93; Dutton, Compacts and Trade Barrier Controversies (1940) I6 IND. L. J. 204.

${ }^{53}$ See testimony of Frank Bane, I2 T. N. E. C. Hearings, supra note 1 , No. 10, at $27 \mathrm{r}$.

st Final Report and Recommendations of the Temporary National Economic Committee, SEN. Doc. No. 35, 77th Cong., Ist Sess. (194I) 34 .

is See letter from Vice-President Wallace, when Secretary of Agriculture, to Senator O'Mahoney, 12 T. N. E. C. Hearings, supra note I, No. 15 , at 472 .

${ }^{5 B}$ Adopted Jan. 23, I94I, the Resolutions read as follows: "Whereas; the National Conference on Interstate Trade Barriers, held in Chicago in April, 1939, considered at length the barriers which obstruct the free flow of commerce throughout the nation in agriculture, industry, labor and other fields, and whereas as a result of this Conference and of the work of those participating in it existing trade barriers were repealed, and new ones aborted, blocked and retoed, and 
being concentrated on observing the course of the trade barrier movement in the 43 state legislatures which meet in r94r. If these states fail to achieve needed legislative revision, it may be taken as an indication that some type of joint federalstate undertaking is a requirement for the solution of this problem.

\footnotetext{
"Whereas; free trade among the several states is imperative in the interest of national defense and the promotion of unity,

"Now therefore be it resolved that this General Assembly request the Council of State Governments, through its Commissions on Interstate Cooperation, to continue this important work by:

"I. Discouraging the introduction in the legislatures of trade barrier bills or of any retaliatory legislation by states which feel themselves aggrieved by the legislation of their neighbors.

"2. Encouraging repeal of trade barrier legislation which may have already been adopted by the several states.

"3. Encouraging the enactment of uniform laws, and the adoption of reciprocal agreements or interstate compacts which have for their aim the reduction of trade barriers between the states.

"4. Initiating regional hearings throughout the United States, such hearings to be officially called by the Commissions on Interstate Cooperation in conjunction with the Council of State Governments, in order to follow through the recommendations made by this General Assembly and by the National Conference on Interstate Trade Barriers.

"5. Urging Governors to veto legislation which would clearly result in the crection of additional trade barriers.

"6. Establishing a Joint Committee on Federal-State relations for the purpose of considering trade barrier problems having to do with federal-state relations.

"Be it further resolved that in order to provide facilities for the conciliation of specific differences between states resulting from trade barriers, this General Assembly recommends that the State which considers itself adversely affected by the legislation of another state petition the Council of State Governments to use its good offices to arrange a conference with the State which has enacted the offending legislation before taking any other action."
} 